Article

\title{
Hegemonic Religions, Majoritarianism, and the Legitimate Limits of Governmental Religious Bias
}

\author{
Nahshon Perez $\mathbb{D}$ \\ Department of Political Studies, Bar Ilan University, Ramat Gan 5290002, Israel; nahshonp@gmail.com
}

Received: 17 July 2020; Accepted: 20 August 2020; Published: 25 August 2020

check for updates

\begin{abstract}
Recent major court decisions and important political events in democratic countries demonstrated, explicitly or implicitly, governmental bias in favor of a given religious tradition. Some prominent cases include the Swiss minarets ban of 2009, the 2011 ECtHR decision in the Lautsi case (Lautsi vs. Italy (2011) Application No. 30814/06) as well as the recent decision of the U.S. Supreme Court in the American Legion v. American Humanist Association case (No. 17-1717, 588 U.S. (2019), legitimizing the usage of public funds to maintain the Maryland Bladensburg Cross. Major scholars, such as David Miller, Joseph Weiler, and Cecile Laborde suggested a novel, detailed argument, justifying the rights of majorities in given countries to structure religion-state institutions following the majority religion, as long as the rights of minority communities and individuals are upheld. The aim of the current article is twofold: First, in section one, we shall attentively define the 'religious majoritarian approach' (RMA), that upholds the presumed rights of majorities to structure religion-state institutions according to the majority-religion. The core features of the RMA will be defined, and three pre-conditions the model requires in order to 'fit' any given case will be described ('shared understanding'; 'tradition' and 'democratic challenge'). Second, in section two, once we have a precise understanding of the RMA, to suggest a critical discussion of this approach. For the sake of the argument, and in order to enable a proper conversation with RMA proponents, this article will not assume that the RMA is illegitimate to begin with, as would be the case if our starting point would have been some version of liberal-neutrality. Rather, the main critical argument will be that the positive case for the RMA is under-studied. In 'positive', it would mean here the arguments for the RMA, rather than focusing on the mere permissibility of it. After all, if a government wishes to adopt a certain policy, it is not sufficient to argue that it does not violate certain moral or legal standards, rather, the citizens of said country would like to know what is the utility of this policy? What does it attempt to achieve? How is it justified? The 'positive' examination of the RMA will be divided into two categories: The first, examining the merits and plausibility of the pre-conditions and the arguments made by RMA scholars themselves. Therefore, in cases in which they are not met, the RMA should be rejected according to the RMA itself. The second is to confront RMA models with further critiques and difficulties, focusing on concerns raised regarding the entanglement between religion and state that the RMA entails, from the perspective of both religion and government. Somewhat schematically, we can label the former critique as 'internal', and the latter as 'external'.
\end{abstract}

Keywords: majoritarianism; established church; endorsed church; American Legion; Lautsi; public spaces; David Miller

\section{Defining the Religious-Majoritarian Approach}

Majorities or their representatives in certain democratic countries and locations, who are identified with particular religions, at times aim to shape, in various ways, the religion-state institutions in their countries, in manners that demonstrate the dominance of their religion vis-a-vis other faiths. We term this phenomenon as the religious-majoritarian approach (RMA). This section begins with a short 
presentation and definition of this approach, moves to present its main justifications, and following, three pre-conditions which must be satisfied in order for the implementation of the RMA to be legitimate are identified, while the second section critically engages with this approach.

The RMA adopts, as its point of departure, the claim that there are substantial majorities in some countries (or states in federal countries) that share religious understandings which, typically, reflect long standing traditions. Such majorities, the RMA argues, can legitimately use governmental acts and policies to advance their religious traditions while constructing or maintaining religion-state institutions, as long as such policies do not violate the rights of minority groups (or non-observant members of these majority groups). ${ }^{1}$

Recently, RMA style views ${ }^{2}$ have gained wide legal recognition from leading courts, such as the European Court of Human Rights (ECtHR), ${ }^{3}$ and received scholarly justification from important political and legal theorists such as David Miller (2016a, 2016b, pp. 145-49), Weiler (2012, 2013), Richard. Garnett (2018), and Laborde and Laegaard (2019). ${ }^{4}$ David Miller aptly captures the main characteristics of the RMA, as he writes: "[a] majority is entitled to ensure that the appearance of public space reflects its own cultural values, so that where those values reflect a Christian heritage, it can insist that Christian buildings and symbols should remain hegemonic" (Miller 2016a, p. 448). ${ }^{5}$

Interestingly, the RMA treats the religious motivated structuring of religion-state institutions ${ }^{6}$ as a topic to be determined by majority vote, in the sense that a given majority can shape such institutions according to its preferences. This point is explained by Garnett (discussing the Maryland Bladensburg Cross, italics added): "Religion-and-public-life questions are important and (sometimes) hard ... why isn't the best way to answer them not through ahistorical judicial ruminations on symbols' all-things-considered communicative content or psychological impact but instead through politics and the practice of civic friendship, with an appropriate respect for the traditions we inhabit and inherit?" (Garnett 2018, p. 3); and here is Laborde: "When religion does not exhibit the features that make it impermissible as an object of state endorsement, then there is nothing wrong with the state endorsing it" (Laborde 2017, p. 115). ${ }^{7}$

Importantly, the RMA connects majoritarian preferences to the accumulation of multi-generational traditions, in the sense that such preferences are grounded in long standing customs, traditions, and a given heritage. Here is Judge Bonello of the ECtHR, in his concurring opinion-in favor of the Italian law that mandates the display of crucifixes in all public school classrooms-in the Lautsi case: "On a human rights court falls the function of protecting fundamental rights, but never ignoring that customs are not passing whims. They evolve over time, harden over history into cultural cement. They become defining, all-important badges of identity for nations, tribes, religions, individuals." (p. 38); and here

1 RMA scholars have different versions of what is the normative threshold that RMA policies should not cross, see further discussion in the text.

2 The term RMA is of the author, not of the analyzed scholars, courts, or laws. Adopted here is a Dworkinian approach, in which a correct interpretation and understanding of a social institution lies in a proper description and analysis of the central and patterned aspects of that institution. As Dworkin argues, in the context of law: "But the purposes in play are not (fundamentally) those of some author but of the interpreter. Roughly, constructive interpretation is a matter of imposing purpose on an object or practice in order to make of it the best possible example of the form or genre to which it is taken to belong (Dworkin 1986, p. 52)."

3 See: Lautsi vs. Italy (2011), Application No. 30814/06. ECHR. On this case, see (Temperman 2012; Thompson 2019).

4 The contemporary scholar most identified with the 'shared understandings' view is Walzer (1983).

For further analysis of Miller's ideas see (Thompson 2019; Zellentin 2014).

6 RMA scholars have paid much attention to the particular RMA techniques connected to public spaces. However, as Miller (2019) and Perez and Fox (2018) argue, the techniques of state support of religion are much more diverse. Therefore, the analysis of the current article applies to many other forms of state support of religion, as long as they follow the 4 features of the RMA listed in the text above. On public spaces, see (Chiodelli and Moroni 2014, p. 169).

7 Laborde indicated three conditions that should be met in order for a governmental endorsement of religion to be legitimate: justification (the policy can be justified in non-denominational specific terms), the general governmental position is inclusive (the policy does not violate civic equality, especially for vulnerable minorities); the policy is limited (the policy is not comprehensive-leaving sufficient space for each citizen to maintain sufficient autonomy in religious and ethical matters); see (Laborde 2017, chp. 4); the description here is a simplified version of Laborde's theorizing. 
are Laborde and Laegaard: "large numbers of Europeans continue to maintain formal affiliation with traditional churches, which they see as part of what it means to be a member of the national community" (Laborde and Laegaard 2019, p. 178).

Such customs and traditions are, as Shils described, embodied in: "material objects, beliefs about all sorts of things, images of persons and events, practices and institutions. It includes buildings, monuments, landscapes, sculptures, paintings, books, tools, machines" (Shils 1981, p. 12). Given Shils' accurate observation regarding the wide spectrum of 'tradition', we can expect that the RMA, while justifying the dominance of a particular religion, can be used to justify a wider spectrum of policies. Indeed, the RMA has wider implications to a very wide selection of examples, laws, and policy domains, as will be indicated in the following more specified description of the RMA.

The RMA can be defined as being characterized by the following four elements. ${ }^{8}$ (i) A particular religion receives some form of public support from the state which can take various forms: Official recognition as the state religion, financial support, symbolic recognition, public dominance in public spaces, etc. ${ }^{9}$ (ii) The religion that receives this public support is well defined and differs significantly enough in creed and/or practice to be distinct from other religions or other denominations of the same religion. (iii) Members of the supported religion enjoy some advantage that is not shared by all citizens, whether it is expressed in financial, symbolic, or other forms. For example: There may be public financial support available only for the dominant religion; the weekly cycle and yearly national holidays may be modeled on the calendar of this religious tradition; the symbols of the preeminent religion may be utilized in the national flag, incorporated in state symbols, mandatorily included in public education, etc. Note that these advantages make adherence to the supported, (typically) majority religion more attractive and often less expensive (socially and financially) than adherence to non-supported religions. (iv) The supported religion is seen as an essential part of the state and there is strong identification of the state with this particular religion.

The RMA is a well-known approach that is embodied in various European countries. Typically, such countries have a formal state church (England, Greece), though many countries adopt the so-called endorsed-church model, i.e., the advancement of a certain religion-by financial support, symbolic representation, special legal status, and other policies-without formally recognizing the supported religion as a formal state church/religion (e.g., Italy; Fox 2015, chp. 3-4). To conclude this characterization of the RMA, it is important to bear in mind that a government that aims to guarantee dominance to a given religion, will have a rich 'menu' of policy options at its disposal, and it can be expected that such an approach will have implications in laws, regulations, budgetary items, and so on. ${ }^{10}$

Two main justifications were suggested for the RMA: That it is grounded in the shared understandings or (more prosaically put) in the majority rule of the relevant public, and second, that the RMA follows long established traditions. We shall present each in turn. ${ }^{11}$

The first justification claims the following: If a religion is widely shared by the relevant public, the relevant population gains the right to structure religion-state institutions according to its preferences, as Weiler writes: "Is it not odd, the argument would go, that under freedom of religion I may be entitled to give expression to my faith at the individual level, but, even if theoretically every single one of my fellow citizens feels exactly like me, we may not give any expression of such in the public square?"

8 See Whelan (1990) for an early discussion of the characteristics of established and endorsed churches models; Laegaard (2017) and Spinner-Halev (2000) offer a normative analysis of such models.

9 There is a debate in the relevant case law whether the Cross is a religious symbol. For the purposes of this article, the approach of the ECtHR in the Lautsi case, that it is a religious Christian symbol ("The Court further considers that the crucifix is above all a religious symbol"; Lautsi, para. 66, majority decision), and that of the U.S. Supreme Court in the American Legion decision ("the cross is undoubtedly a Christian symbol"; Syllabus, para. D, majority opinion written by Justice Alito)—also identifying it as a religious symbol (although it might also have other meanings), is the interpretation most adequate.

10 See (Miller 2019; Perez and Fox 2018).

11 Aside from the RMA, there are traditionalist views of the good life and state, supportive of established churches, (McConnell 1995). 
(Weiler 2012, p. 765; see also Miller 2016a, p. 448; Garnett 2018, p. 3). ${ }^{12}$ Note that this justification is grounded in the idea of majority rule, ${ }^{13}$ and furthermore, makes the structure of religion-state institutions a topic of mundane politics, rather than a constitutional matter.

A second justification for the RMA is grounded in the concept of tradition. Put simply, this justification's main claim is that structuring religion-state institutions following a given tradition is an important factor in the wellbeing of the population whose identity is intertwined with the noted tradition. ${ }^{14}$ Furthermore, the tradition justification creates a linkage between the shared understandings justification and the noted tradition: According to this linkage, the widely shared, multigenerational tradition brings about or 'fathers' the wide majority, which supports governmental policies that aim to keep the noted religious tradition hegemonic. An interesting formulation of the 'tradition' justification was offered by Weiler: "religion, in this thick cultural sense, could and did become an important and at times constitutive element in the self-understanding of persons as a collective people. In short, in the cultural make-up of the nation, religion may play a huge part even for those who have abandoned its deistic content." (Weiler 2012, p. 761; see also Miller 2016b, pp. 145-48 which makes a similar claim). To conclude this second justification, the RMA is justified via the importance of religious tradition to the individual wellbeing, in the sense that if not given adequate or even dominant position in the governmental-religious model, a constitutive aspect of the identity of the majority of the public will suffer a severe setback.

Moving forward, the RMA, according to the model's noted own internal logic, assumes that the following three pre-conditions must be fulfilled or satisfied in order to make the implementation of this model legitimate to begin with. Note that these conditions are merely necessary, not sufficient, for the implementation of the RMA in any given polity. The reason is that even if these conditions are met, it only means that the RMA 'fits' a given case, to allow the rationality of the material implication of the RMA to this case, it says nothing of the desirability of such an application. Indeed, the justification granted for the RMA must be persuasive, on top of being appropriate or being in adequate fit to, a given case.

First, it must be possible to empirically identify a substantial majority that shares identifiable religious understandings (henceforward, the 'shared understandings' condition, see first justification above); second, it must be possible to identify and follow, within reasonable contours, and via historical data, past traditions and customs that have been transmitted from generation to generation (henceforward, the 'tradition' condition, see second justification above). These traditions need to be established over a significant timeframe: "at the minimum, two transmissions over three generations are required for a pattern of belief or action to be considered a tradition" (Shils 1981, p. 15).

Note that the two empirical pre-conditions are actually more precise formulations of some of the non-formal terms that are endorsed by Miller ('heritage', 'majorities', 'hegemonic'), Weiler ('every

12 There are instances in which individual values and preferences are not 'translated' to collective public policy. For example, dislike of a minority group by a majority should not ground public policy that would discriminate against this minority group; individual preference for comfort (say, using a certain environmental-affecting practice) should not lead to a public policy permitting it as it would, if permitted, lead to hazardous collective outcomes. Weiler's point, to be persuasive, requires some principle permitting a transformation of individual values to collective public policy, which was not presented. [On this argument see (Barry 1990) (in the context of freedom of religion); (Sunstein 2005) (in the context of environmental policies)].

13 The importance of majority rule in democratic theory has been defended by Robert Dahl: "If citizens disagree on policies, whose views should prevail? The standard answer in democratic systems is that the decision must follow the will of the majority of citizens, or in representative systems, the majority of their representatives ... I shall not undertake to justify majority rule except to say that no other rule appears to be consistent with the assumption that all citizens are entitled to be treated as political equals" (Dahl 2006, pp. 14-15).

14 Lord Devlin's conservative essay (the Enforcement of Morals) makes a similar claim: “ ... law exists for the protection of society. It does not discharge its function by protecting the individual ... the law must protect also the institutions, and the community of ideas, political and moral, without which people cannot live together ... if the reasonable man believes that a practice is immoral ... and is honest and dispassionate- that no right minded member of his society could think otherwise, then for the purpose of the law it is immoral" (Devlin 1965, pp. 22-23). 
single one'), and judge Bonello ('They [customs] evolve over time, harden over history into cultural cement') in the quotes given above.

Third, it must be clear that adopting the RMA will not violate the rights of the individuals who are not members of the majority religion (henceforward, the 'democratic challenge' condition). Note that RMA scholars emphasize that the RMA must coexist with adequate respect towards minority rights. As Miller argues: “ . . some policies that might attract majority support should nonetheless not be enacted. The clearest example would be policies that infringe the human rights of a minority of citizens, but one can go further: majority decisions must comply with the principle of equal treatment of all citizens even when human rights are not at stake. Of course, this does not mean that in the case of any particular decision there cannot be winners and losers" (Miller 2016a, p. 441). Yael Tamir makes a similar point in her recent book: "Meaningful communities are, by their very nature, appealing to some and exclusionary for others" (Tamir 2019, p. 157).

Here, however, we need to proceed carefully, there are significant differences in the moral and legal limits of RMA models according to different scholars. While the basic logic of the RMA is compatible with a limited governmental inegalitarianism vis-a-vis its citizens in the religious sphere, the measure of permissible inegalitarianism is in dispute among RMA scholars, such as Miller (2016a), Weiler (2013), and Laborde and Laegaard (2019). If we add to this list the views of justices of important courts that made decisions that pertain to the RMA, such as the U.S. Supreme Court-in the American Legion recent case-we reach even greater variation.

Hence, in order to accurately describe the RMA, it is perhaps advisable to think of the permissible governmental created religious bias in favor of a given religion as a continuum. This continuum begins with a maximalist view of the permissible religious bias and entanglement of government and religion, allowing significant religious favoritism but stopping short of actual religious coercion, as described by Justice Thomas of the U.S. Supreme Court-in the American Legion recent case: "In an action claiming an unconstitutional establishment of religion, the plaintiff must demonstrate that he was actually coerced by government conduct that shares the characteristics of an establishment as understood at the founding" (Thomas, concurring in Judgment, p. 3). Next in our described continuum we have J. Weiler, who stops the level of permissible governmental bias in favor of a given religion in a standard of non-discrimination vis-a-vis all citizens, in the sense that the identity of the state as religiously identified, is, according to Weiler, disconnected from the rights of individuals to non-discrimination (Weiler 2013, p. 766). Next on our continuum we can find Miller's standard (2016a, 2019) described above, that of the equal treatment of all citizens, which is more demanding than Weiler's 'non-discrimination', since equal treatment extends to further spheres of policy, and hence would allow less religious favoritism. Finally, allowing the least leeway for legitimate governmental religious inegalitarianism we have Laborde and Laegaard (2019), following Laborde (2017), as they insist that such inegalitarianism should meet the triple standard of accessibility, inclusiveness, and limitedness; that is, the public policy that supports a statist religious identity should be supported by reasons that are accessible to non-believers; such a policy should not harm civic inclusiveness, and lastly, be limited in scope as to allow each citizen autonomy in moral and religious beliefs. Arguably, this is why Laborde and Laegaard choose as an example to their argumentation, state usage and adoption of religious symbolism, rather than, say, funding of faith schools, paying the salary of clergy, or other policies that would require higher levels of governmental direct support of religion, that are more likely to violate at least one of the indicated conditions.

In what follows, we shall not attempt to somehow force all different RMA positions into one standard; rather, we shall simply indicate that different policies will be evaluated differently by the noted RMA scholars. ${ }^{15}$

15 Note that RMA scholars focus their attention on religious and national minorities, in the sense that the 'democratic challenge' refers to the way RMA policies should avoid violating the rights of national and religious minorities. However, RMA 
Moving on, any attempt to justify the adoption of the RMA as a model of religion-state relations must demonstrate the veracity of the two empirical pre-conditions (the 'shared understandings' condition and the 'tradition' condition) with readily available historical and sociological data. Furthermore, any such attempt must also demonstrate the reasonableness of the general normative claim (the 'democratic challenge' condition), and it must do this according to the internal standards of the RMA.

If the 'shared understandings' and 'tradition' pre-conditions are not met in a particular case, the RMA will prove irrelevant or inapplicable to a particular country or state, as the model itself mandates that these two conditions must be met. The 'democratic challenge' pre-condition, in turn, constitutes the key justification that RMA adherents offer for condoning the inherent public, state-sponsored religious inequality of this approach. The successful articulation of such a justification, therefore, is as important as meeting the two prior 'empirical' conditions.

\section{The Religious-Majoritarian Approach: A Critique}

In this section, two kinds of objections to the RMA will be presented; the first, regarding the plausibility of the RMA own preconditions ('internal critiques'), ${ }^{16}$ and the second, further objections, focusing on concerns raised regarding the entanglement between religion and state that the RMA entails, from the perspective of both religion and government ('external critiques'). We shall take each in turn.

\subsection{Internal Critiques of the RMA}

(I). The RMA: Empirical preconditions.

If the RMA position is to be applicable to any given case (country, state, district), it must demonstrate a 'fit' between the model and the case. This means that some sort of evidence must be produced for the two empirical pre-conditions: Shared understandings and tradition. We shall examine both, beginning with the shared understandings pre-condition.

The RMA approach relies on the view that contemporary, modern societies are typified by the existence of shared understandings in matters of religion. This assumption is opposed by the overt reality of religious heterogeneity within modern societies. Indeed, thorough surveying of the populations of large democratic countries (and many countries that are not democratic as well) reveals no agreement over religion and morals; it is a truism of modern political theory that this condition of pluralism - and not a condition of shared understandings that is required by the RMA—is a constant feature of modern societies. ${ }^{17}$

Here, RMA scholars can simply abandon the language of shared understandings in favor of denoting a simple, prosaic democratic procedure of some majority decision: The results of a referendum, a majority of judges in a court of law, a vote in the parliament, and so on. This step would prevent the problem of grounding the RMA in a notion of shared understandings, which would be in tension with current, well-researched, sociological data. ${ }^{18}$ However, it would also introduce three further points. First, 'shared understandings' or 'self-understanding of collective people' no longer ground the RMA, rather what grounds the RMA is some straightforward mechanism as a vote in the parliament. Second, the emphasis on democratic procedures helps to clarify the magnitude, or lack thereof, of support granted to the noted RMA style policy. For example, in the Swiss minarets referendum (Stephens 2009), the decision to ban the building of minarets was supported by $57.4 \%$ of voters, while around $53 \%$

policies will also impact other minorities, such as sexual minorities. This is an important blind spot for RMA scholars and requires a different analysis. On sexual minorities and nationalism see (Walker 1997).

16 The choice of this version of critique enables a conversation with RMA proponents (and see the debate regarding 'internal critique' at Tadros 2009).

17 See a 2014 report by the Pew center: (Pew 2014); see (Dworkin 2000, p. 229), for this pluralist-empirical view in political theory.

18 (Pew 2014). 
of citizens voted (Stephens 2009). These dry, limited numbers clarify the distance between actual data and the language of collective identity. Lastly, if what grounds the RMA are majority decisions it should be carefully verified that the conditions that lead to majority decisions are proper; that is because they may well be made under conditions in which unfair limitations shape the decision itself. In such cases, the supposed majoritarian claim should be flatly rejected. ${ }^{19}$ This required 'fairness of procedures' standard, beyond the regular requirements of any democratic procedure (lack of duress, adequate availability of relevant information etc.), will also demand careful scrutiny of decisions that might be the result of indoctrination of children. As such, decisions such as Lautsi, that had to do with the placing of a religious symbol in all public schools, will be especially suspect. Indeed, it is hardly surprising, that a mandatory placement of crucifixes in the children's environment leads to a preference of having them. However, preferences formed in this way cannot ground the RMA, as B. Williams (Williams 2008) famously argued in this context: "the acceptance of a justification does not count if the acceptance itself is produced by the coercive power which is supposedly being justified" (Williams 2008, p. 6).

These specifications do not rule-out the shared understandings condition on analytical grounds; rather, they simply operationalize it to its empirical, plain ingredients. Notably, the translation of 'shared understandings' to 'majority vote' is an improvement, as terms such as 'shared understandings' or 'collective identity' leave an impression of an 'essence' of a country or a nation, while 'majority vote' is a simple and familiar attribute of democratic political processes, that can be easily understood and then reversed by a similar democratic procedure.

Moving to the tradition pre-condition, historical evidence tends to reveal the fragility of such supposedly static traditions. A series of historians and scholars, writing on the growth of the modern state and the creation of modern nationalities, have shown that many 'traditions' are actually the result of a process of unification and homogenization of diverse populations with diverse cultural and religious understandings. National 'traditions' are often recent innovations whose origins are spuriously projected back into time with the aim of legitimizing current political institutions. ${ }^{20}$ Therefore, turning to 'tradition' is often a justificatory tactic-aiming to support current policies-with debatable historical credentials. ${ }^{21}$ Furthermore, the countries examined by RMA scholars, such as Switzerland, Italy, and the state of Maryland in the U.S. are all advanced, modern, capitalist societies. Such locations are typified by very quick changes, technological, societal, occupational, and others. The famed sociologist Zygmunt Bauman typified such societies as locations where: "It is now all too easy to choose identity, but no longer possible to hold it" (Bauman 1996, p. 50; Waldron 1991). Put succinctly, Bauman and Waldron both claim that the views that past traditions still have a significant, constant, and widespread hold in modern capitalist societies should be viewed skeptically. These specifications do not rule-out the tradition pre-condition, however they do imply that claims regarding tradition should be supported by some kind of evidence, rather than just being raised or stated.

(II). The RMA: normative precondition; the democratic challenge.

Moving from the empirical to the normative sphere, the principles of the RMA demand that it would be absolutely clear that no rights of individuals who are not members of the majority religion would be violated as a result of a given government adopting a RMA model ('the democratic challenge'). As explained by Weiler: "allowing a religiously inspired identitarian asset to the state but insisting on strict non-discrimination on grounds of religion" (Weiler 2013, p. 766). As noted above, different RMA scholars understand in different ways the permissible limits of the RMA, a point that we shall address momentarily.

19 See (Elster 1983, pp. 109-40).

20 Gellner declared: "Nationalism is not the awakening of the nations to self-consciousness: it invents nations where they do not exist" (Gellner 1964, p. 169; Anderson 2006, p. 6; Scott 1998).

21 See (Weber 1976, p. 113; Gellner 2008; Abizadeh 2004). 
Now, many liberal theorists, as well as advocates of the model of separation between religion and state, would reject any attempt by a democratic government to adopt the RMA in principle. According to their view, a liberal state should never side with a given religion: RMA style policies are illegitimate as, by definition, they inherently discriminate against citizens of the state that are members of minority religions or are non-religious (Dworkin 1978; Nussbaum 2008). ${ }^{22}$ Furthermore, liberal scholars, it is important to remember, were skeptical with regard to the persuasive strength of the concept of tradition even when it is empirically verified, as for example, argued by Hart and Dworkin in their famous debate with Lord Devlin, and so do liberal scholars in the present who return to examine the kind of traditionalist arguments presented by Lord Devlin. ${ }^{23}$

However, for the purposes of the current article, we shall allow for the idea that RMA policies are permissible, as otherwise we shall move too far from the empirical reality typifying many European democracies (and Canada), which are the focus of RMA argumentation. We shall hence assume that the RMA is not a-priory wrong or impermissible. Rather, we shall simply engage with the arguments of Miller, Weiler, and Laborde and Laegaard as they themselves understand them, as this would enable a fruitful conversation with RMA principles.

The RMA model argues that liberal governments may legitimately support one religion as described above. However, the RMA can lead to a great variety of policies. These diverse policies will be evaluated differently by RMA scholars. Indeed, this point is so important that a concretization might be in place. The province of Ontario, Canada, funds faith schools of only one religion (Catholic-Christianity). This policy met significant legal challenges and was eventually deemed as legitimate by the Canadian Supreme Court. ${ }^{24}$ Now, how would RMA scholars evaluate such a policy? Arguably, it would be viewed as impermissible by Laborde and Laegaard (2019), as it would violate their civic inclusion standard. ${ }^{25}$ This policy would probably be viewed as legitimate by Weiler, as non-supported religious groups can fund their own religious schools, and hence should not be counted as a violation of Weiler's non-discrimination standard; it is difficult to assess Miller's view on the matter, as equal treatment of citizens can reasonably be described as both permitting and disallowing this policy-although equal treatment can perhaps be plausibility interpreted as disallowing such a policy, as there is an ouverte differentiation among citizens according to religious identity-however this is a complex case, and was indeed judged differently by the Canadian Supreme Court that held the policy as permissible, ${ }^{26}$ while the U.N. Human Rights Committee in 1999 held it as impermissible. ${ }^{27}$

The point here is not nit-picking regarding each scholar's position; rather it aims to clarify that according to some RMA scholars, numerous religious policies of democratic countries such as Canada would be viewed as impermissible, and this includes Laborde and Laegaard and (probably) Miller, with only Weiler viewing such policies as permissible. The implication of this diversity of policies and RMA standards is that the range and kind of RMA legitimate policies, that would be 'approved' by all RMA scholars is rather narrow, and would exclude policies such as the noted Canadian policy of unequal, exclusive funding of faith schools, the content of the noted Swiss referendum, and probably familiar attributes of democratic countries with established or endorsed churches, such as exemptions

22 Further examples of liberal theorists that would reject the RMA would arguably include Jones's (1994) view of the liberal principle that each religious individual should internalize the cost of her/his religious belief; similarly positioned is Schwartzman's (2017) view of the function of public justification.

23 See (Hart 1963; Dworkin 1966; Lecce 2008).

24 See: Adler v Ontario (AG) [1996] 3 S.C.R. 609.

25 The challenge to Ontario's policy was brought about by Jewish citizens of the province, who asked that a policy will be created that funds their faith schools as well; Laborde and Laegaard indicate Jews as a minority that should be of special concern to their standard of civic inclusion (Laborde and Laegaard 2019, p. 180).

26 See: Adler v Ontario (AG) [1996] 3 S.C.R. 609.

27 See: Waldman v. Canada (Communication No. 694/1996). 
given to governmental funded religious associations from non-discrimination rules, as such cases violate both the 'civic inclusion' and the 'equal treatment' standards, plausibly interpreted. ${ }^{28}$

Moving on, we wish to focus on those cases that are within the legitimate range of RMA policies according to all three RMA scholars. As other cases will be disputed even according to RMA scholars themselves, and as our aim is to further our understanding of the RMA position, it would be useful to attempt to evaluate those cases that are clearly within the contours of legitimate RMA policies.

So, let us proceed to evaluate a policy which meets the 'democratic challenge' in a way that is within the legitimate contours of the RMA according to all three RMA scholars, say, the Bladensburg Cross case. This now famous case, decided by the U.S. Supreme Court, accepted as legitimate the continued placing of a large cross in Bladensburg, Maryland, commemorating fallen soldiers of the First World War; the cross is placed on public land and maintained by public funds.

It is reasonable to assess that all three RMA scholars would evaluate this case as permissible, for the following reasons: the placing and maintaining of the cross is not coercive, as no person is obligated by its presence to become a Christian, worship in any way, etc. The presence of the cross can be described as vestigial (it was established in 1919), it hence seems to meet even Laborde and Laegaard's strict standards, and hence $a$ fortiori, would meet Miller's and Weiler's standards. ${ }^{29}$

Assuming that we interpreted the views of these scholars correctly, what counter arguments directly connected to the 'democratic challenge' (as plausibly understood by RMA scholars) should be raised in the context of even non-coercive religious symbols? Two seem most relevant, both of which question whether RMA scholars correctly classify as legitimate relevant RMA style policies.

First, the designation 'non-coercive symbols', or 'passive symbols', does not mean that such symbols lack any influence. A recent article using data from the medical professions, argues as follows: "Where does the cognitive neuroscience matter? Calibrating communicative impact in light of the neuroscience data debunks the notion that visual religious symbols are somehow less powerful than text as an empirical matter, or "passive" due to their visual nature". (Haupt 2014, p. 869). Viewing religious symbols in such an 'active' way, might bring them into the illegitimate 'range' of governmental religious policy according to Laborde and Laegaard, and even within the illegitimate range according to Miller, as if a religious symbol is as powerful as a text, a religious symbol endorsed by the government might fail both the civil inclusiveness test and the equal treatment standard, as it signals to citizens a hierarchy of preferred beliefs according to the government, a divisive act.

Second, even legitimate RMA cases still should face the possibility that the RMA can deteriorate into illegitimate policies that violate the rights of members of minority religions, or those of non-observant members of the majority religion. The reason for this concern is the experience of the actual politics that surround the RMA, especially as was seen at the events surrounding the Swiss minarets referendum of 2009.

However, a preliminary explanation is required here, as a reader might simply note that a deterioration of permissible governmental policies into illiberal acts is hardly unique to the religion-state realm. While certainly true, the RMA requires from the government or a court of law, to make rather subtle distinctions regarding the contours of permissible state bias towards one religion, while at the same time aiming to provide one faith with social and legal dominance. The former requires a nuanced ability at making legal and institutional distinctions, the latter accepts as legitimate the wish of one group in the society to gain a hegemonic (or at least a strongly advantageous) status. This odd coupling should clarify why the RMA should be specifically scrutinized for its expected inability to

28 These cases involve governmental funded religious associations that request exemptions from generally applicable laws. Such exemptions permit firing employees following attributes protected in regular labor contexts. Such exemptions expectedly violate Miller's 'equal treatment', Laborde and Laegaard's 'civic inclusiveness', and arguably even Weiler's 'non-discrimination' standard, yet such practices by the noted associations were found legitimate by the ECtHR in the Martinez case (Martinez v. Spain application No. 56030/07, 2014), and by the Canadian Supreme Court in the Caldwell case (Caldwell et al. v. Stuart et al., [1984] 2 S.C.R. 603). For a discussion of such cases see (Shorten 2010, 2019; Perez 2020).

29 The vestigial attribute of a given religious symbol is designated as a proxy for its legitimacy by Laborde and Laegaard (2019). 
distinguish between legitimate policies according to its own standards, and those that violate these same standards. ${ }^{30}$

Indeed, in the Swiss referendum, the outcome was one, that according to Miller himself, went beyond what a RMA model would view as legitimate (Miller 2016b, pp. 145-49). Furthermore, in the heated debate in Switzerland regarding the referendum over minarets, many images and the general public discourse portrayed Muslims — en masse — as vile, violent, and dangerous (Mayer 2011). In other words, even if one accepts a qualified defense of the minarets ban in principle (Miller 2016a, p. 454), and attempts to carefully define the contours of the RMA in a way that would not violate the rights of minority faiths, it can still be pointed out, that expected illegitimate policies and appalling public discourse will typify attempts to allow a faith based majority to structure religionstate institutions according to its faith.

While a differentiation between vestigial and new forms of RMA can help to make this warning more precise, as vestigial forms of the RMA are less likely to create this deterioration, ${ }^{31}$ the RMA seems to pose similar phenomena that were recognized in the context of liberal nationalism and its potential transformation into ethnic nationalism (as argued by Weinstock 1996; Mayerfeld 1998; Gerson and Rubin 2015).

\subsection{External Critiques of the RMA}

At this point, we can turn to an overall evaluation of the RMA. As such, we can assess this suggested policy while not being tied to the perspectives of RMA scholars and their specified argumentation. The RMA, after-all, is a recent version of an established or endorsed church model. Such models have won the attention of scholars of various disciplines (political science, law, history, and religion), who argued that even if such models are permissible, it is ill advised for the government to choose a given religion to advance to an advantageous or hegemonic status. A brief mention of those arguments is therefore certainly relevant if we wish to assess the RMA.

So, let us assume, for the sake of the argument, that in a given case the pre-conditions required for the RMA are met (both empirical and normative pre-conditions). The RMA seems to assume, that in such a case, a statereligion alliance, in which the state chooses one religion and provides it with an advantageous status and/or conditions in the variety of policies that the RMA can support, is a welcomed development for both the state and the chosen religion. This view, however, is anything but trivial. For the state and religion to be entangled in such an intimate way, many complex policy steps need to be made, many of which would not be welcomed by religious scholars of diverse faiths. Furthermore, numerous political theorists and legal scholars expressed concerns about the political mechanisms required for such an entanglement of religion and state.

Let us begin with the religious 'side' of this entanglement (to be followed with the political 'side'), with a concrete example. In an Amici Curiae submitted to the United States Court of Appeals (Ninth Circuit) regarding the permissibility of public funds used to maintain the noted Maryland Bladensburg Cross, the Baptist joint committee for religious liberty wrote as follows: "Where the government endorses one religion over all others, it weakens the sanctity of that religion and its beliefs. The religious symbol becomes the official marker of the government, representing a host of individuals who do not subscribe to that religion, rather than keeping the symbol one of an individual or faith community. The

30 As explained by D. Enoch, in the context of his clarification of the logic of slippery slope arguments: "Generalizing, a slippery slope argument is an argument against an action (A) that is not in itself objectionable, based on the claim that performing it will lead to the performance of (B, which will lead to $C$, which will lead to the performance of ... ) some other-objectionable - action (Z), because we are liable to fail to abide by the proper distinction between $\mathrm{A}$ and $\mathrm{Z}$ (Enoch 2001 , p. 631). Note that the odd coupling discussed above explains why, in the particular case of the RMA, a slippery slope worry is relevant.

31 See (Laborde and Laegaard 2019). 
symbol and the religion are thereby degraded" (Baptist Joint Committee 2017, pp. 23-24). ${ }^{32}$ What this example teaches us, is that a governmental appropriation of a religious symbol will not be welcomed by the faith who holds this symbol to be sacred.

Importantly, such concerns were also made by non-Christian faiths. A similar argument made from a religious perspective, wary of governments co-opting religious principles, doctrines or symbols, was made in the Islamic context, via the celebrated legal scholar of Islamic legal traditions, An Naim, as he claimed that: "Sharia principles cannot be enacted and enforced by the state as public law and public policy ... if such enactment and enforcement is attempted, the outcome will necessarily be the political will of the state and not the religious law of Islam. The fact that ruling elites sometimes make such claims to legitimize their control of the state in the name of Islam does not mean that such claims are true" (An Naim 2010, p. 1). In the Jewish context, the late Jewish Philosopher Yeshayahu Leibowitz, wrote that "counterfeit religion identifies national interests with the service of God and imputes to the state-which is only an instrument serving human needs—supreme value from a religious standpoint" (Leibowitz 1992, pp. 226-27; Rubin 2013).

These religious scholars are wary from scenarios in which religious doctrines, beliefs, practices, and symbols are being appropriated by the state. The result being that political usages, foreign to the religious tradition itself, would fundamentally change the original theological meanings attributed to such symbols, artifacts, expressions, concepts, and so on. ${ }^{33}$

Moving to the political 'side', for the state to be able to choose one religion to support, a considerable knowledge regarding the specific religion, its core beliefs and practices (and internal divisions) needs to be collected, analyzed and decided upon. This will create clear entanglement of the state with religion (and raises severe problems regarding privacy), and it is far from obvious that this is a task that the state should take upon itself, for at least two reasons. First, this is a task that the state is ill-equipped to handle, as Locke argued regarding political leaders: "Neither their right to rule nor their skill in ruling entails certain knowledge of other things, let alone of true religion. If it did, how does it come about that in matters of religion the lords of different countries differ so much from one another?" (Locke 2010, p. 19). ${ }^{34}$ Second, as Quentin Skinner (Skinner 2012) argued in his analysis of republicanism, it is anything but clear that the 'marriage' of state and religion will bring about positive results for the state, as he writes: “To preserve our liberty, we need above all to possess virt'u; but to possess virt' $u$ is to be willing to place the salvation of our community above all personal considerations, whereas Christianity instructs us to treat our personal salvation as more important than anything else" (Skinner 2012, p. 181). This classic republican concern indicates that religion and state do not always share the same goals. ${ }^{35}$

Now, one can easily locate in the rich history of church-state relations further reasons following which both religion and state should aim to maintain adequate distance one from the other. These reasons would include the socially divisive implications of a government siding with one religion among many, ${ }^{36}$ or the fear that religions will have to surrender much information regarding their internal mechanisms, practices, beliefs, and believers to the government as to be de-facto co-opted

32 An identical claim was made in the dissenting opinion of Justices Ginsburg and Sotomayor in the American Legion U.S. Supreme court decision (pp. 4,8); the majority opinion, as mentioned above, did not mandate the removal of the cross.

33 See the arguments made by A. Koppelman (2013, chp. 2), how governmental support of religion corrupts religion. Stanley Hauerwas, a famed contemporary Christian-theologian, argued similarly: “ ... we shall pollute our Christian faith by making of it a civil religion" (Hauerwas 2001, p. 478).

34 For contemporary proponents of this view see (Aronson 2017).

35 The idea that religion and state have different goals is accompanied by data collected by social scientists, indicating strong reservations regarding instrumental functions that the fusion of religion and state supposedly aims to fulfil (Finke and Stark 1998).

36 The famous legal expression of the concern regarding the divisive potential of governmental bias toward one religion, is the quote from the 'Lemon' decision of the U.S. Supreme Court: "political division along religious lines was one of the principal evils against which the First Amendment was intended to protect". In Lemon v. Kurtzman (1971) [403 U.S. 602, 622], Chief Justice Burger delivered this opinion. 
by the state. ${ }^{37}$ One especially important type of modern sets of critiques raised against established churches stems from the economic analysis of religion, arguing that privatization of religion creates incentives for religions to become moderate, efficient, and better suited to the values of believers; and that such bottom-up religious activities bring about the flourishing of religious activity, and yield positive externalities, supportive of the development of democratic regimes (Finke and Stark 1988; Rothstein and Broms 2013).

For the purposes of this article, we do not need to 'decide' whether the separation model is superior to the RMA, rather, and somewhat less dramatically, the point is to simply present the argument, that contrary to the RMA position that views the 'marriage' between religion and state as desirable from the perspective of both the chosen, supported religion and the state, there are, in the history and in the contemporary variants of political, legal, and religious thought, important counter arguments, strongly indicating that such entanglement is undesirable for both the state and religion.

Note, that the argument here does not claim that the RMA is illegitimate, or impermissible. As a recent empirical study has indicated, the mere policy of unequal support of religion by democratic countries does not diminish confidence in public institutions by religious minorities (Perez et al. 2017). Indeed, David Miller effectively summarized the empirical findings of Perez et.al vis-a-vis the debate regarding the permissibility of having an established church: "Although confidence in institutions such as parliament and government is not a perfect proxy for a subjective feeling of non-alienation, it would be surprising if the alleged marginalising effect of establishment on religious minorities failed to dent their political confidence at all, which is what the evidence suggests (indeed the data presented in this article shows government support for religion having a small positive effect on minorities' confidence in their political institutions" (Miller 2019, f.n. 24). As such, it is not likely that adopting a RMA model constitutes, in and of itself, a rights violation that should be somewhat mitigated or even invalidated by the courts. However, the mere fact that a given policy is not harmful is very different than saying that it should be adopted.

\section{Conclusions}

This article attempted to describe and define the religious majoritarian approach (RMA), and following, to critically evaluate it. The RMA aims to legitimize the structuring of religion-state institutions following the religious preferences of majorities in democratic countries. In the first part of this article, this approach was described as having four main features: (i) A particular religion receives some form of public support from the state; (ii) the religion that receives this public support is well-defined; (iii) members of the supported religion enjoy some advantage that is not shared by all citizens; and (iv) the supported religion is seen as an essential part of the state. The RMA model presents two main justifications: That it is grounded in the shared understandings of the majority of citizens, and that it reflects well established traditions. Once we had in front of us the structure of the RMA as a general approach to religion-state relations, we turned to a critical evaluation of the RMA. Three main points presented themselves. First, the RMA relies on the veracity of two empirical pre-conditions that have to be verified for each particular case (country, state, locality), for the RMA to be considered as relevant for any specific location. These are the shared understandings and tradition conditions. Importantly, the tradition pre-condition is in tension with well-established research regarding modernity and religious-national traditions. This makes its applicability to many cases doubtful given observational data regarding the historical and social details of such cases. Second, the RMA must meet an additional pre-condition, that it is compatible with safeguarding

37 The notion that religion should be wary of the state is not new. See, for example, how J.A. Watt, a scholar of Christian religion-state relations in the middle ages, expresses this point: "Popes of the early middle ages, concerned to halt imperial intervention in ecclesiastical affairs, had emphasized God's division of the powers and his will that neither power should usurp what was proper to the other's sphere ... sensitive to the need to conserve libertas ecclesiae" (Watt 1988, p. 378; see also Tierney 1982). A. Ravitzky indicated similar concerns sounded in classical Jewish sources (Ravitzky 2002, p. 88). 
the rights of minorities. This compatibility is non-trivial, given the diversity of policies that the RMA can support and the different standards that evaluate such policies indicated by different RMA scholars. What should be inferred from this point is that the extent of RMA legitimate policies according to RMA scholars is rather narrow, and would disallow the religious policies adopted even by well-established democracies such as Canada (the noted governmental funding of faith schools of only one denomination) and Switzerland (the results of the 2009 minarets ban referendum).

Third and last, even if all three pre-conditions are met, the RMA should still pass a common- sense political test, in that there are strong arguments, from the perspective of both the state and religion, why a fusion of both is undesirable. Especially powerful among those is the wish of religions to keep their autonomy and to protect themselves from the danger of being co-opted by the state; and the data provided by the economic analysis of religion, indicating the flourishing of religious activity in countries that adopt the separation model.

To conclude this essay, it seems that the adoption of the RMA, although narrowly permissible from the perspective of liberal democratic theory, is highly debatable. Indeed, even in those cases in which all three noted pre-conditions are met, it is evident that there are strong reservations-from both religious and political sources-against this suggested policy.

Funding: This research was supported by an Israel Science Foundation grant number 688/18.

Acknowledgments: The author would like to thank the following for their valuable feedback on previous drafts of this article: Simon Thompson, Sune Laegaard, Yuval Jobani, Victor Tadros, Peter Jones. The paper was presented at the ASPP conference in Newcastle (June 2019), and the feedback received is gratefully noted.

Conflicts of Interest: The author declares no conflict of interest.

\section{References}

Abizadeh, Arash. 2004. Historical truth, national myths and liberal democracy: On the coherence of liberal nationalism. Journal of Political Philosophy 12: 291-313. [CrossRef]

An Naim, Abdullahi Ahmed. 2010. Islam and the Secular State. Cambridge: Harvard University Press.

Anderson, Benedict. 2006. Imagined Communities: Reflections on the Origin and Spread of Nationalism. London and New York: Verso Books. First published 1983.

Aronson, Ori. 2017. The How Many Question: An Institutionalist's Guide to Pluralism. In Institutionalizing Rights and Religion. Edited by Leora Batnitzky and Hanoch Dagan. Cambridge: Cambridge University Press, pp. 147-63.

Baptist Joint Committee. 2017. Amici Curiae Submitted to United States Court of Appeals (Ninth Circuit). Available online: https://www.americanbar.org/content/dam/aba/publishing/preview/publiced_preview_ briefs_pdfs_07_08_08_472_RespondentAmCuBJC.pdf (accessed on 1 May 2020).

Barry, Brian. 1990. How not to defend liberal institutions. British Journal of Political Science 20: 1-14. [CrossRef]

Bauman, Zygmunt. 1996. Morality in the Age of Contingency. In Detraditionalization. Edited by Paul Heelas, Scott Lash and Paul Morris. Oxford: Blackwell, pp. 49-59.

Chiodelli, Francesco, and Stefano Moroni. 2014. Typology of spaces and topology of toleration: City, pluralism, ownership. Journal of Urban Affairs 36: 167-81. [CrossRef]

Dahl, Robert. 2006. On Political Equality. New Haven: Yale University Press.

Devlin, Patrick. 1965. The Enforcement of Morals. Oxford: Oxford University Press.

Dworkin, Ronald. 1966. Lord Devlin and the enforcement of morals. The Yale Law Journal 75: 986-1005. [CrossRef]

Dworkin, Ronald. 1978. "Liberalism”. In Public and Private Morality. Edited by Stuart Hampshire. Cambridge: Cambridge University Press, pp. 113-43.

Dworkin, Ronald. 1986. Law's Empire. Cambridge: Harvard University Press.

Dworkin, Ronald. 2000. Sovereign Virtue: The Theory and Practice of Equality. Cambridge: Harvard University Press. Elster, Jon. 1983. Sour Grapes. Cambridge: Cambridge University Press.

Enoch, David. 2001. Once you start using slippery slope arguments, you're on a very slippery slope. Oxford Journal of Legal Studies 21: 629-47. [CrossRef]

Finke, Roger, and Rodney Stark. 1988. Evaluating the evidence: Religious economies and sacred canopies. American Sociological Review 54: 1054-56. [CrossRef] 
Finke, Roger, and Rodney Stark. 1998. Religious choice and competition. American Sociological Review 63: 761-66. [CrossRef]

Fox, Jonathan. 2015. Political Secularism, Religion, and the State: A Time Series Analysis of Worldwide Data. Cambridge: Cambridge University Press.

Garnett, Richard. 2018. Symposium: The End of a Walking Dead Doctrine? SCOTUSblog (Dec. 11, 2018, 1:03 PM). Available online: https://www.scotusblog.com/2018/12/symposium-the-end-of-a-walking-dead-doctrine/ (accessed on 1 May 2020).

Gellner, Ernest. 1964. Thought and Change. London: Weidenfeld and Nicolson.

Gellner, Ernest. 2008. Nations and Nationalism. Ithaca: Cornell University Press.

Gerson, Gal, and Aviad Rubin. 2015. Cultural nationalism and liberal values: An elusive synthesis. International Political Science Review 36: 197-213. [CrossRef]

Hart, Herbert Lionel Adolphus. 1963. Law, Liberty, and Morality. Palo Alto: Stanford University Press.

Haupt, Claudia E. 2014. Active Symbols. B.C.L. Rev. 55: 821.

Hauerwas, Stanley. 2001. A Christian Critique of Christian America. In The Hauerwas Reader. Edited by John Berkman and Michael Cartwright. Durham: Duke University Press, pp. 459-80.

Jones, Peter. 1994. Bearing the consequences of belief. Journal of Political Philosophy 2: 24-43. [CrossRef]

Koppelman, Andrew. 2013. Defending American Religious Neutrality. Cambridge: Harvard University Press.

Laborde, Cécile. 2017. Liberalism's Religion. Cambridge: Harvard U.P.

Laborde, Cécile, and Sune Laegaard. 2019. Liberal Nationalism and Symbolic Religious Establishment. In Liberal Nationalism and Its Critics. Edited by David Miller and Gina Gustavsson. Oxford: Oxford University Press.

Laegaard, Sune. 2017. What's the problem with symbolic religious establishment? The alienation and symbolic equality accounts. In Religion in Liberal Political Philosophy. Oxford: Oxford University Press, pp. 118-31.

Lecce, Steven. 2008. Against Perfectionism: Defending Liberal Neutrality. Toronto: University of Toronto Press.

Leibowitz, Yeshayahu. 1992. Judaism, Human Values, and the Jewish State. Translated and Edited by Eliezer Goldman. Cambridge: Harvard University Press.

Locke, John. 2010. A Letter Concerning Toleration. In Locke on Toleration. Edited by Richard Vernon. Cambridge: Cambridge University Press. First published 1689.

Mayer, Jean-François. 2011. A country without minarets: analysis of the background and meaning of the Swiss vote of 29 November 2009. Religion 41: 11-28. [CrossRef]

Mayerfeld, Jamie. 1998. The myth of benign group identity: A critique of liberal nationalism. Polity 30: 555-78. [CrossRef]

McConnell, Michael W. 1995. Establishment and Toleration in Edmund Burke's" Constitution of Freedom". The Supreme Court Review 1995: 393-462. [CrossRef]

Miller, David. 2016a. Majorities and minarets: Religious freedom and public space. British Journal of Political Science 46: 437-56. [CrossRef]

Miller, David. 2016b. Strangers in Our Midst. Cambridge: Harvard University Press.

Miller, David. 2019. What's Wrong with Religious Establishment? Criminal Law and Philosophy, 1-15. [CrossRef]

Nussbaum, Martha. 2008. Liberty of Conscience: In Defense of America's Tradition of Religious Equality.. New York: Basic Books.

Ravitzky, Aviezer. 2002. Religion and State in Jewish Philosophy. Jerusalem: The Israel Democracy Institute.

Perez, Nahshon. 2020. Governmental-Funded Religious Associations and Non-Discrimination Rules: On Immunity and Public Funding. Canadian Journal of Law \& Jurisprudence 33: 341-67.

Perez, Nahshon, and Jonathan Fox. 2018. Normative theorizing and political data: Toward a data-sensitive understanding of the separation between religion and state in political theory. Critical Review of International Social and Political Philosophy, 1-25. [CrossRef]

Perez, Nahshon, Jonathan Fox, and Jennifer M. McClure. 2017. Unequal state support of religion: On resentment, equality, and the separation of religion and state. Politics, Religion \& Ideology 18: 431-48.

Pew. 2014. Available online: https://www.pewforum.org/2014/04/04/global-religious-diversity/ (accessed on 1 May 2020).

Rothstein, Bo, and Rasmus Broms. 2013. Governing religion: the long-term effects of sacred financing. Journal of Institutional Economics 9: 469-90. [CrossRef]

Rubin, Aviad. 2013. The status of religion in emergent political regimes: lessons from Turkey and Israel. Nations and Nationalism 19: 493-512. [CrossRef] 
Schwartzman, Micah. 2017. Religion, Equality and Anarchy. In Religion in Liberal Political Philosophy. Edited by C. Laborde and A. Bardon. Oxford: Oxford U.P., pp. 15-30.

Scott, James C. 1998. Seeing Like a State: How Certain Schemes to Improve the Human Condition Have Failed. New Haven: Yale University Press.

Shils, Edward. 1981. Tradition. Chicago: University of Chicago Press.

Shorten, Andrew. 2010. Cultural exemptions, equality and basic interests. Ethnicities 10: 100-26. [CrossRef] Shorten, Andrew. 2019. May churches discriminate? Journal of Applied Philosophy 36: 709-17. [CrossRef] Skinner, Quentin. 2012. Visions of Politics: Volume 2, Renaissance Virtues. Cambridge: Cambridge U.P. Spinner-Halev, Jeff. 2000. Surviving Diversity: Religion and Democratic Citizenship. Baltimore: JHU Press.

Stephens, Thomas. 2009. Minaret Result Seen as a Turning Point. Swissinfo. Available online: http://www. swissinfo.ch/eng/minaret-result-seen-as--turning-point-/7793740 (accessed on 1 May 2020).

Sunstein, Cass R. 2005. Cost-benefit analysis and the environment. Ethics 115: 351-85. [CrossRef]

Tadros, Victor. 2009. Law, Strategy and Democracy: A Response to Duff. Journal of Applied Philosophy 26: 269-75. [CrossRef]

Tamir, Yael. 2019. Why Nationalism. Princeton: Princeton University Press.

Temperman, Jeroen, ed. 2012. The Lautsi Papers: Multidisciplinary Reflections on Religious Symbols in the Public School Classroom. Leiden: Martinus Nijhoff Publishers, vol. 11.

Thompson, Simon. 2019. The expression of religious identities and the control of public space. Ethnicities 19: 231-50. [CrossRef]

Tierney, Brian. 1982. Religion, Law, and the Growth of Constitutional Thought, 1150-1650. Cambridge: Cambridge University Press.

Waldron, Jeremy. 1991. Minority cultures and the cosmopolitan alternative. University of Michigan Journal of Law Reform 25: 751.

Walker, Brian. 1997. Social movements as nationalisms or, on the very idea of a queer nation. Canadian Journal of Philosophy 26: 505-47. [CrossRef]

Walzer, Michael. 1983. Spheres of Justice: A Defense of Pluralism and Equality. New York: Basic books.

Watt, John A. 1988. Spiritual and Temporal Powers. In The Cambridge History of Medieval Political Thought. Edited by Jean H. Burns. Cambridge: Cambridge University Press, pp. 367-423.

Weber, Eugen. 1976. Peasants into Frenchmen: The Modernization of Rural FRANCE, 1870-1914. Palo Alto: Stanford University Press.

Weiler, Joseph HH. 2012. Freedom of Religion and Freedom from Religion: The European Model. Maine Law Review 65: 759.

Weiler, Joseph H. H. 2013. Lautsi: A reply. International Journal of Constitutional Law 11: 230-33. [CrossRef]

Weinstock, Daniel M. 1996. Is there a moral case for nationalism? Journal of Applied Philosophy 13: 87-100. [CrossRef] Whelan, Frederick G. 1990. Church Establishments, Liberty and Competition in Religion. Polity 23: 155-85. [CrossRef] Williams, Bernard Arthur Owen. 2008. In the Beginning Was the Deed: Realism and Moralism in Political Argument. Princeton: Princeton University Press.

Zellentin, Alexa. 2014. Freedom, equality, minarets. Res Publica 20: 45-63. [CrossRef]

\section{Court Cases}

Canada

Caldwell et al. v. Stuart et al., [1984] 2 S.C.R. 603.

Adler v Ontario (AG), [1996] 3 S.C.R. 609.

Waldman v. Canada (Communication No. 694/1996). 1999; U.N. Human Rights Committee.

ECtHR: Lautsi vs. Italy. 2011. Application No. 30814/06.

Martinez v. Spain application No. 56030/07, 2014.

U.S.

Lemon v. Kurtzman, (1971) [403 U.S. 602].

American Legion v. American Humanist Association. No. 17-1717, 588 U.S. (2019). 